\title{
Uma Pandemia Viral em Contexto de Racismo Estrutural: Desvelando a Generificação do Genocídio Negro
}

\author{
Paula Rita Bacellar Gonzaga ${ }^{1}$ \\ ${ }^{1}$ Universidade Federal do Sul da Bahia, BA, Brasil.
}

\author{
Vivane Martins Cunha ${ }^{2}$ \\ ${ }^{2}$ Universidade Federal de Minas Gerais, MG, Brasil.
}

\begin{abstract}
Resumo: Para compreender o mundo contemporâneo é imprescindível voltar o olhar para a colonização das Américas e a escravização dos povos indígenas e negros, pois esses processos históricos e políticos construíram as estruturas das sociedades modernas. A partir da colonização produziu-se a racialização dos corpos, que estabeleceu uma hierarquia de vida e de morte. Logo, o racismo torna-se a base do direito de matar. O negro é fabricado como insígnia da morte, sendo desumanizado e submetido à violência racial-colonial e também à de gênero. Este ensaio se propõe a tecer reflexões sobre o modo como o racismo modula, e também é modulado, no contexto pandêmico da Covid-19, além de salientar um contínuo histórico de violências raciais que reencenam o passado colonial. Para isso, tomaremos como cerne do debate as experiências das mulheres negras, haja vista que suas posicionalidades nas estruturas de poder permitem observar e analisar as realidades sociais numa perspectiva contra-hegemônica e insurgente. Dispor as experiências das mulheres negras enquanto lócus privilegiado de produção de conhecimento sobre a realidade nacional brasileira alicerça o entendimento das consequências do racismo no tecido social, assim como visibiliza resistências históricas ao Estado genocida.
\end{abstract}

Palavras-chave: Racismo, Pandemia da Covid-19, Mulheres Negras.

\section{A Viral Pandemic in the Context of Structural Racism: Unveiling Black Genocide}

\begin{abstract}
Looking back towards the colonization of the Americas and the enslavement of indigenous and black peoples is essential to understand the contemporary world, as these historical and political processes built the structures of modern societies. The colonization produced racialized bodies, establishing a life/death hierarchy. Thus, racism becomes the foundation of the right to kill. The black is manufactured as a death insignia, dehumanized and subjected to racial-colonial violence, as well as of gender. This essay aims to reflect how racism modulates and is modulated in the context of the Covid-19 pandemic, besides highlighting a historical continuum of racial violence that reenact the colonial past. To this end, black women's experiences comprise the core of the debate, as their role within the power structures allow us to observe and analyze social realities from a counter-hegemonic and insurgent perspective. By arranging black women's experiences as a privileged locus of knowledge production on the Brazilian reality, we may understand the consequences of racism based on the social fabric and expose historical resistance to the genocidal state.
\end{abstract}

Keywords: Racism, Covid-19 pandemic, Black Women. 


\title{
Una Pandemia Viral en el Contexto del Racismo Estructural: Develando la Generificación del Genocidio de la Población Negra
}

\begin{abstract}
Resumen: Para entender el mundo contemporáneo es fundamental mirar la colonización de América y la esclavitud de los pueblos indígenas y de los negros, ya que estos procesos históricos y políticos han construido las estructuras de las sociedades modernas. La colonización conllevó la producción de una racialización de los cuerpos que estableció una jerarquía de vida y muerte. Por tanto, el racismo se convirtió en la base del derecho a matar. El negro se fabrica como insignia de la muerte, y es deshumanizado y sometido a violencia racial-colonial y de género. Este ensayo tiene como objetivo reflexionar sobre la forma en que el racismo modula, y también se modula, en el contexto pandémico de Covid-19, además de resaltar una historia continua de violencia racial que recrea el pasado colonial. Para ello, tomaremos las vivencias de las mujeres negras como eje del debate, dado que sus posiciones en las estructuras de poder nos permiten observar y analizar las realidades sociales desde una perspectiva contrahegemónica e insurgente. Disponer de las vivencias de las mujeres negras como un lugar privilegiado de producción de conocimiento sobre la realidad nacional brasileña sustenta la comprensión de las consecuencias del racismo en el tejido social, además de mostrar la resistencia histórica al Estado genocida.
\end{abstract}

Palabras clave: Racismo, Pandemia de Covid-19, Mujeres Negras.

\section{Por mortos ainda não enlutados: um país sem memória e vítimas sem memoriais}

Muito tem se dito acerca da necessidade de se lembrar nominalmente das vítimas da pandemia da Covid-19. São, no momento da escrita deste texto, mais de 100 mil pessoas vitimadas fatalmente pelo novo agente do coronavírus no território brasileiro. Essa demanda por resguardar a memória é extremamente legítima e nos convoca a pensar o luto em sua condição de elaboração do sujeito frente à própria mortalidade, assim como a importância de tecer memoriais às vítimas de grandes tragédias, como forma de recuperar o valor de cada indivíduo para sua família, para sua comunidade e para nossa frágil ideia de humanidade irmanada pela morte inevitável, mas, muitas vezes, antecipada por relações desiguais, violentas, genocidas. Memoriais foram erigidos às vítimas do regime nazista alemão, bem como para aquelas que sucumbiram nos escombros das torres gêmeas, em 2001, nos Estados Unidos da América, como um monumento à vida dessas, mas também como marcadores de momentos que podemos e devemos evitar reviver.

$\mathrm{Na}$ América Latina necessitamos de memoriais. A organização das nações a partir do marco civilizatório colonial instaurou a raça como princípio biológico de hierarquização social, mas, principalmente, como parâmetro de humanidade forjado a partir do modelo branco, masculino e heterossexual (Carneiro, 2005; Lugones, 2008). Sob o argumento da desumanização, deu-se o genocídio de pessoas indígenas e negras, essas sequestradas no continente africano e trazidas para esse lado do oceano em navios de tortura onde muitas pereceram pela dor, pela fome ou pelo desespero (hooks, 2020). Logo, são mortes não enlutadas publicamente porque sequer foram reconhecidas como vidas pelo paradigma humanista branco ocidental, sendo corpos descartáveis para os regimes de poder e de violência racial-colonial (Rodríguez, 2017).

O domínio colonial, fundado na classificação racial, expandiu-se pelo mundo, tornando-se o novo padrão de poder mundial que, ainda hoje, dita a distribuição de lugares e de papéis sociais nas estruturas de poder (Quijano, 2005), utiliza a raça enquanto princípio organizador das relações de dominação e do capitalismo global (Grosfoguel, 2018), assim como determina as possibilidades de vida e desenha roteiros de morte. Portanto, a colonialidade institui identidades e estabelece as proposições de quem deve ou não viver; de quem deve ou não ser lembrada/o; de quais vidas importam. 
A morte imposta se deu também na memória, nos faltam registros de todas as centenas de etnias indígenas que aqui viviam, bem como das inúmeras nações de onde eram originárias as pessoas negras de quem descendemos. Para essas etnias e nações, que erigiram esse país, não há memoriais. Coube aos povos originários a floresta regada pelo sangue dos que resistiram e para o povo negro o Atlântico onde foram sepultados nossos antepassados. Essa história não contada, mal contada, recontada e abafada, alimenta com migalhas os modos de subjetivação das/os herdeiras/os dessa tradição colonial de morte e de apagamento. Sendo assim, o saqueamento da memória e a violência silenciadora alicerçam o genocídio indígena e negro ainda na atualidade.

Por conseguinte, construiu-se um imaginário nacional em que as mazelas e as desigualdades sociais são lidas como decorrências naturais do atraso civilizatório dos povos racializados ${ }^{1}$, sendo esses considerados inadaptados às sociedades modernas capitalistas. Desse modo, as expropriações e as violências raciais-coloniais e pós-coloniais que tornam as vidas indígenas e negras precárias, abjetas e desumanas são páginas arrancadas da história. Apesar de historicamente resistirmos ao terror racial, continuamos cotidianamente submetidas/os à violência racial-colonial, seja no enaltecimento de personagens escravocratas em monumentos e estátuas em vias públicas, ou quando nos deparamos com políticas de Estado neocoloniais que continuam a saquear e roubar terras indígenas e quilombolas. Como sublinha Kilomba (2019, p. 158), "a ferida do presente ainda é a ferida do passado e vice-versa; o passado e o presente entrelaçam-se como resultado".

Tendo em vista a atemporalidade da ferida colonial (Kilomba, 2019), necessitamos de memoriais na América Latina que reconheçam o caráter político das vítimas que tiveram suas vidas ceifadas por escolhas de projetos de Estado sustentados em práticas genocidas, desde os empreendimentos colonialistas até sua roupagem atual de sucateamento dos serviços de saúde, de fragilização dos direitos trabalhistas, de investida sob territórios e corpos por meio da força destrutiva do Estado e seus agentes, militares e paramilitares. Memoriais teriam, então, a função social e política de tratar feridas históricas ao forjar sociabilidades e subjetividades que propiciem o enlutamento público, de modo a restituir a humanidade tradicionalmente negada a suas vítimas, bem como criar fissuras no pacto branco civilizatório baseado em opressões raciais que resultam em assimetrias estruturais e mortes anunciadas.

Desse modo, torna-se preciso disputarmos a construção da memória coletiva da atual pandemia e não contarmos somente números, mas também as histórias das pessoas que perderam suas vidas pelo contágio da Covid-19 e pelos desdobramentos adotados em razão da pandemia. Mais do que isso, é urgente abrirmos outros caminhos que nos façam dar voltas inversas na árvore do esquecimento ${ }^{2}$, tão nutrida e enraizada nesse país, para visibilizar o contínuo entrelaçamento entre o passado colonial e a cotidianidade que segue a selecionar desproporcionalmente, a depender da cor da pele e/ou etnia, os corpos destinados às valas comuns, as mortes que provocam comoção pública e as vidas que mobilizam a proteção da sociedade e do Estado. Assim, é possível ampliar a compreensão que as mortes decorrentes da atual pandemia da Covid-19 não acontecem somente nos hospitais, pois a histórica exposição à morte pela falta de moradia, trabalho, alimentação, saneamento básico e de acesso à saúde, agravadas pela crise sanitária em curso, subtraem ainda mais a possibilidade de vida de parte significativa dos povos indígenas e negros.

Como salienta Mbembe (2017, p. 241), "os acontecimentos não se inscrevem na memória como história, senão no seguimento de um trabalho específico, psicológico e social, isto é, simbólico". Em vista disso, investimos aqui na psicologia como agente enunciador e propositor de transformação, num exercício disruptivo com os enunciados que insistem na

\footnotetext{
${ }^{1}$ Leia-se indígenas e negros. O branco é construído no domínio colonial não como um corpo racializado, ao contrário disso, ele se impõe enquanto modelo absoluto e universal de humanidade. Portanto, os racializados são os Outros que estão abaixou ou fora da escala da humanidade.

${ }^{2}$ Tratava-se de um último ato em que as/os escravizadas/os eram obrigadas/os a fazer antes de saírem definitivamente da África e serem amontoadas/os em navios negreiros. Consistia em dar voltas em uma árvore e não olhar para trás, para que a memória das/ os africanas/os fosse apagada e o passado esquecido. Esse último ato é conhecido principalmente em Benin (Moreira \& Pereti, 2020). Utiliza-se no texto a árvore do esquecimento enquanto metáfora para se referir aos diversos mecanismos violentos de produção de apagamentos, esquecimentos e silenciamentos da existência dos povos racializados que vivem nas Américas.
} 
reiteração de ficções poderosas como a neutralidade e a democracia racial, ambas instrumentos essenciais para a manutenção das relações de poder que corroboram com o extermínio simbólico, epistemológico, psíquico e físico dos povos indígenas e negros. A partir da Psicologia social, comprometida com a dirimição das relações exploratórias e desiguais que devem ser alvo de nossas intervenções, propomos neste texto um memorial analítico que registre os nomes de algumas das inumeráveis vítimas do racismo estrutural em meio à maior crise sanitária de que temos registro e que seguem sendo os corpos alvejados pela omissão e pela ação estatal. A escrita da nossa história está em curso, a muitas e corajosas mãos, bem como a história do saber psicológico que se vê provocado a repensar suas práticas de cumplicidade com o racismo.

\section{Navegando em águas passadas: a instrumentalização da pandemia como ferramenta eugenista}

Em meio à pandemia da Covid-19, alguns atores sociais afirmam que estamos no mesmo barco, uma versão adaptada do mito da democracia racial e sua falaciosa pretensão de que somos um só povo e sofremos dos mesmos males. Porém, como estamos no mesmo barco se o acesso ao atendimento médico e a medicamento da população preta e parda, $69,5 \%$ e $67,8 \%$ respectivamente, é menor do que a população branca, de 74,8\% (Instituto Brasileiro de Geografia e Estatística, 2015)? Como estamos no mesmo barco, se $11,9 \%$ de pessoas pretas e $11,4 \%$ de pardas afirmaram que já se sentiram discriminadas nos serviços de saúde, em contraposição a 9,5\% de pessoas brancas (Instituto Brasileiro de Geografia e Estatística, 2015)? Como estamos no mesmo barco, se a taxa de mortalidade de bebês indígenas cresceu $12 \%$ somente em um ano após o desmonte do Programa Mais Médicos ${ }^{3}$ pelo governo federal em 2019 (Fellet, 2020)? Como estamos no mesmo barco, se as pessoas indígenas e negras são as principais vítimas da Covid-19, além de suas vidas tornarem-se ainda mais precárias pela crise econômica decorrente da atual pandemia (Organização das Nações Unidas, 2020)?
Para além do campo da saúde, navegamos por um abismo racial que não nos deixa esquecer que podemos até remar pelas mesmas águas, mas o racismo distribui desigualmente os recursos necessários para velejarmos. Por isso, precisamos lembrar de cada uma das vítimas da Covid-19 e admitir que boa parte delas é vítima não apenas do novo agente do coronavírus, mas, principalmente, do racismo estrutural que coloca pessoas indígenas e negras em posições de maior vulnerabilidade, aumentando a suscetibilidade ao contágio daquelas que têm menor acesso às possibilidades de prevenção e tratamento; além de acentuar fragilidades, inseguranças e desamparo na obtenção de meios de sobrevivência quem àqueles que já se encontravam alijados de direitos básicos.

Em vista disso, é importante demarcarmos reiteradamente que nunca estivemos no mesmo barco, pois comumente em períodos de aprofundamento de crises econômicas e/ou política, como temos vivenciado no Brasil, são fortalecidos os meios de controles sociais e ideológicos com o objetivo de distorcer realidades históricas, e o não reconhecimento das consequências do racismo é um componente crucial nesse processo, tal como Abdias Nascimento discorre em seu livro $O$ genocídio do negro brasileiro: processo de um racismo mascarado, publicado em 1978 (Nascimento, 1978/2017).

Desde 2013, enfrentamos no Brasil um cenário de acirramento da crise econômica, política e institucional que propiciou a eleição do atual presidente do país, Jair Messias Bolsonaro. Esse governo encontrou um campo fértil para o avanço de políticas de precarização da vida e do fortalecimento de uma plataforma genocida que investe ostensivamente no aparelhamento do Estado às Forças Armadas. Logo, intensificaram-se os discursos políticos e de parcela da sociedade de desqualificação das vidas indígenas e negras, ao mesmo passo em que o Estado recusa ouvir as vozes daquelas/es vitimadas/os pelo racismo e/ou amparar a construção e/ou manutenção de políticas públicas na compreensão das desigualdades sociorraciais. O slogan "minha cor é o Brasil" ${ }^{\text {, }}$ utilizada durante a campanha eleitoral do atual Presidente da República, vende uma imagem desracializada do país

${ }^{3}$ É um programa criado pelo Ministério da Saúde, em 2013, em parceria com estados e municípios, tendo como um dos seus principais objetivos levar mais médicas/os a regiões onde há escassez dessas/es profissionais.

${ }^{4}$ Durante a campanha eleitoral de Jair Messias Bolsonaro, era recorrente a aparição do subtenente do Exército Hélio Fernandes Barbosa Lopes, homem negro de pele retinta, ao lado do então candidato à presidência, vestindo a camisa com o referido slogan: "minha cor é o Brasil". 
que objetiva invisibilizar as marcas do racismo no tecido social, reforçando a ficção de que todas/os usufruem dos mesmos acessos e privilégios que essa terra tem a ofertar, a despeito do contínuo derramamento de sangue indígena e negro em seu solo.

Por consequência, há um desmonte gradativo da produção de informação a partir do não preenchimento do quesito raça/cor em registros oficiais de órgãos estatais, além da não divulgação de dados já existentes. Em relação à pandemia, a maioria dos estados imprimiu uma cortina de fumaça que oculta e/ou deturpa informações etnorraciais das/os infectadas/os pela Covid-19, assim como suas vítimas fatais. Essa escolha política permite identificar ao menos dois pontos relevantes para analisar os meandros sofisticados de sustentação de políticas genocidas no Brasil. O primeiro relaciona-se à intenção de apagar o retrato do país que revela as desigualdades sociorraciais amplificadas pela atual pandemia. O racismo estrutural modula os determinantes sociais envolvidos no processo de saúde-adoecimento, instituindo um continuum que desde o Brasil colônia mata o povo negro de "doença da pobreza", "doenças negligenciadas" e "doenças evitáveis” (Jesus, 2020), tal como ocorre com os povos indígenas.

Para auxiliar no entendimento da dimensão da assimetria racial no Brasil, podemos destacar a água potável, direito humano universal basilar para a sustentação da vida, como uma amostra expressiva da iniquidade social e do racismo ambiental. O Censo de 2010, realizado pelo Instituto Brasileiro de Geografia e Estatística, identificou que mesmo a população negra (51\%) sendo maior que a população branca (48\%), há uma sobrerrepresentação negra (61\%) sem cobertura no abastecimento de água potável, em contraposição à população branca (37\%) (Jesus, 2020). Verificou-se também que o abastecimento de água em terras indígenas pela rede geral de distribuição era de apenas 33,6\% (Instituto Brasileiro de Geografia e Estatística, 2010). A violação desse direito fundamental geralmente sedimenta outras vulnerabilidades que são cumulativas, tais como a falta de saneamento básico e de moradia adequada.
Ao desconsiderar os contextos de desigualdades sociorraciais da sociedade brasileira, tais como as mencionadas acima, o Estado não se sente coibido em reiterar sua posição de desprezo às vidas indígenas e negras, tal como ocorreu nos vetos presidenciais no Projeto de Lei $n^{\circ} 1142 / 2020^{5}$ (Neide, 2020) que obrigava o Estado a promover o acesso universal à água potável, de distribuir cesta básica e material de higiene, limpeza e desinfecção para aldeias e comunidades indígenas, além de garantir a oferta emergencial de leitos hospitalares e de unidade de terapia intensiva (UTI) e a aquisição ou disponibilização de ventiladores e de máquinas de oxigenação sanguínea, entre outras proposições interditas. Evidencia-se, então, um consistente quadro político-epidemiológico que compõe o controle racializados dos corpos (Jesus, 2020) e a fomentação de itinerários de mortes devido à desproteção do Estado traçados no passado colonial que ainda segue a pavimentar o presente dito democrático. A violência racial-colonial deixou como legado uma sucessão de sofrimentos que não causa como resposta "nem tomada de responsabilidade, nem solicitude, nem simpatia e nem sequer a piedade" (Mbembe, 2017, p. 13) com os corpos que são rotineiramente deixados para morrer.

Desse modo, o ocultamento do abismo racial é um importante artifício utilizado para limpar as mãos sujas de sangue do Estado e escamotear seus traços genocidas, com o intuito de se desresponsabilizar, inclusive criminalmente $^{6}$, pela potencialização da exposição à morte dos povos indígenas e negros; sendo esse o segundo ponto a ser destacado. Considerando o descumprimento da Portaria no $344^{7}$ (Brasil, 2017) do Ministério da Saúde que tornou obrigatório, em 2017, o preenchimento do quesito raça/cor nos formulários dos sistemas de informação em saúde, várias ações judiciais foram movidas no país com o objetivo de reverter tal apagamento racial das informações sobre a contaminação e a mortalidade pela Covid-19, tendo o protagonismo de organizações da sociedade civil, entre elas do movimento negro. Além disso, outras radiografias da atual crise sanitária têm sido implementadas por iniciativas

\footnotetext{
${ }^{5}$ Dispõe sobre medidas urgentíssimas de apoio aos povos indígenas em razão do novo coronavírus (Covid-19).

${ }^{6}$ O Partido Democrático Trabalhista (PDT) denunciou Jair Messias Bolsonaro ao Tribunal Penal Internacional (TPI) por crime contra humanidade devido a suas ações e omissões em relação à pandemia da Covid-19.

${ }^{7}$ Dispõe sobre o preenchimento do quesito raça/cor nos formulários dos sistemas de informação em saúde, publicada no Diário Oficial da União na edição de 2 de fevereiro de 2017.
} 
não governamentais que buscam reverter a persistente subnotificação de casos, disputar narrativas em defesa das memórias das vítimas, além de visibilizar e buscar fortalecer suas estratégias de resistência frente ao descaso estatal, tais como a Plataforma de monitoramento da situação indígena na pandemia do novo coronavírus (Covid-19) no Brasil (Covid-19 e os Povos Indígenas, 2020) e o Observatório da Covid-19 nos Quilombos (Instituto Socioambiental \& Coordenação Nacional de Articulação das Comunidades Negras Rurais Quilombolas, 2020).

O que apresentamos até o momento é apenas uma pequena parte de um cenário muito amplo que há mais de 500 anos esfacela as possibilidades e as potencialidades da existência de vidas indígenas e negras nesse país. Sendo assim, entre barcos, canoas e porões de navio, seguimos navegando por um abismo racial. Sem os mesmos recursos para navegar em suas águas, nesse momento ainda mais revoltosas, a morte é sempre dada como um horizonte próximo e inevitável para pessoas indígenas e negras, principalmente as residentes em favelas e periferias. As ações e as omissões do Estado frente à sobrerrepresentação de mortes de pessoas indígenas e negras pela Covid-19 nos convocam a refletir se a atual pandemia foi integrada às suas trincheiras de guerra de matriz eugenista, de modo a acelerar processos de eliminação de corpos tidos como indesejáveis, desvelando, assim, o possível uso político do novo agente do coronavírus na produção de uma limpeza social.

Desse modo, quem está sendo protegida/o se as remoções de ocupações urbanas, as operações policiais em favelas e as ações de garimpeiros em terras indígenas aumentaram durante a atual pandemia? Quem está sendo protegida/o se Lucas Morais da Trindade, 28 anos de idade, condenado a 5 anos e 10 meses de prisão por portar aproximadamente 10 gramas de maconha, teve três pedidos de habeas corpus negados e perdeu a vida em um presídio ao contrair a Covid-19? Quem está sendo protegida/o se o trabalho doméstico em muitos estados está inserido como serviço essencial, tirando vidas de mulheres trabalhadoras como Socorro Freitas? Os questionamentos são inesgotáveis e somente reforçam a constatação que o racismo retira a humanidade de vidas indígenas e negras, destituindo-as de proteções sociais mínimas contra as variadas formas de violações e de violências que recaem em seus corpos. Logo, parte significativa das narrativas de proteção da Covid-19 são como coletes salva-vidas moldados somente para caber em alguns corpos.

A pandemia não é uma problemática que possamos isolar das bases hierárquicas sob as quais construímos a sociedade brasileira, por isso seus efeitos são marcadamente atravessados por gênero, raça, classe e geração, sendo inúmeros os contornos que podemos assumir para exemplificar essas reverberações. Neste texto, optamos por compreender como cenas de continuidade histórica são significativas na composição das vítimas fatais do novo agente do coronavírus e também os desdobramentos da pandemia e das medidas de prevenção, tal como o isolamento social, afetam a vida das mulheres negras.

\section{Cleonice, Marta, Mirtes e Miguel: Em nome da mulher, da mãe e do filho}

Em 17 de março, o Rio de Janeiro teve sua primeira vítima fatal da pandemia da Covid-19. A repetição de manchetes que identificavam uma empregada doméstica infectada pela patroa que havia voltado de uma viagem à Itália provocaram a filósofa Djamila Ribeiro a escrever em sua coluna à Folha de São Paulo sobre a solidão institucional que vitimou até pós-morte essa trabalhadora (Ribeiro, 2020). Apagada por significantes coloniais ainda tão caros às nossas relações de trabalho, a empregada doméstica é recorrentemente reduzida a um lugar de objeto da casa, propriedade da família, sem nome. O trabalho doméstico é uma instituição da colonialidade e se repete mundo afora pela exploração de mulheres consideradas inferiores por se distanciarem do marco da branquitude. Shohat (2002) compreende que a imposição da limpeza como tarefa fatalmente relegada àquelas que não são brancas e recorrentemente são alvo de ofensas racistas sobre seu cheiro, sua higiene, sua cor, são formas de perpetuação de uma lógica hierárquica racial sobre a pressuposição de quem deve viver da repetição da manutenção da vida de outrem sem identidade, privacidade e direitos.

No Brasil, a figura da empregada doméstica é considerada um emblema da suposta superioridade das classes abastadas. Como indica Quijano (2005), a hierarquização do trabalho pelo critério de superioridade racial relegou aos negros e indígenas a escravidão e a servidão, respectivamente, e ainda na atualidade os alijam dos cargos de melhor remuneração e prestígio social. Góes, Ramos e Ferreira (2020) denunciam que se o distanciamento social é a principal 
medida de proteção, cabe pensar quem poderá ficar protegido, haja vista que as pessoas negras são maioria em trabalhos informais e de baixa remuneração que, em larga medida, continuaram funcionando durante a pandemia, como o setor do comércio, do transporte, da indústria e do serviço doméstico.

De acordo com a presidenta da Federação Nacional das Trabalhadoras Domésticas (Fenatrad), Creuza Maria Oliveira, as mulheres negras são expostas a condições mais precárias de trabalho devido à inserção precoce no mercado de trabalho, dificuldade de acessar o ensino formal e por serem mães jovens ${ }^{8}$. A análise da presidenta da Fenatrad cabe à história da carioca Cleonice Gonçalves que trabalhava desde os 13 anos de idade como empregada doméstica e aos 63 anos foi contaminada em exercício de sua função laboral ao ser convocada a trabalhar na casa da patroa diagnosticada com Covid-19. Cleonice é a primeira vítima fatal da pandemia no Rio de Janeiro, nosso cartão postal nacional, e as condições que levaram à sua morte caracterizam o nosso país em sua gênese estruturalmente racista e sexista. A perpetuação da tradição escravocrata de exploração de mulheres negras no âmbito do trabalho doméstico é um dos exemplos mais fidedignos do racismo estrutural. Gonzales (1984) indica que apenas duas funções são outorgadas às mulheres negras na sociedade brasileira: domésticas e mulatas, ambas ramificações das figuras coloniais da mãe preta e da mucama. A reprodução da mulher negra como aquela que deve prover ilimitadamente o cuidado, ainda que sob parca remuneração, tem sido reforçada na literatura, nas produções audiovisuais e em publicações reificantes do racismo científico que reforçam a ideia dessas como seres biologicamente programados à sujeição.

No Rio de Janeiro, Cleonice foi a primeira, mas, infelizmente, não foi a última. Acompanhamos ao longo dos últimos meses o posicionamento de prefeitos, governadores e até mesmo do Presidente da República de que o trabalho doméstico deve ser considerado um trabalho essencial. Sem dúvida a manutenção da vida - alimentação, higienização da casa, das roupas - é um trabalho imprescindível, valioso e ininterrupto. No entanto, a delegação de atividades domésticas para outrem a custo de arriscar a vida dessa pessoa é considerar o próprio conforto superior à existência daquele que o serve. $\mathrm{O}$ estado do
Pará, por exemplo, decretou que o trabalho doméstico fosse considerado essencial enquanto se anunciava a ausência de vagas nos hospitais da capital. Ora, mas para onde irão as empregas domésticas vitimadas pela pandemia e impelidas a seguir trabalhando? Cleonice Gonçalves morreu num hospital municipal, era usuária do Sistema Único de Saúde (SUS), assim como a maior parte das trabalhadoras domésticas, e a exposição ao risco se deu no ambiente de trabalho. A solidão institucional a que Djamila Ribeiro se refere é a iniquidade da justiça em não considerar a empregada doméstica enquanto trabalhadora cujos direitos devem ser protegidos frente ao patrão, haja vista que nossa tradição colonial insiste em colocá-la como recurso disponível aos que habitam as casas grandes atuais, recursos que podem ser explorados, emprestados e substituídos.

Mayorga (2013) já sinalizava em 2013 que a Psicologia é uma profissão majoritariamente feminina e branca, portanto, realizada por mulheres que para manter o exercício do trabalho comumente delegam o cuidado da casa e das/os filhas/os a trabalhadoras domésticas, essas preponderantemente negras. No contexto da pandemia, em que o direcionamento dos protocolos internacionais de prevenção a Covid-19 é de ficarmos em casa em isolamento social, o Correio Braziliense noticiou que o Conselho Federal de Psicologia registrou entre março e abril de 2020, 51.747 solicitações para exercício online da profissão (Lima \& Cardim, 2020), esse número é maior do que todas as solicitações da história do sistema Conselhos, que somadas chegavam até então a 30.677. Não sabemos, no entanto, qual a porcentagem entre essas psicólogas que para atender remotamente solicitou que outra mulher deixasse suas/seus filhas/os, sua segurança e atravessasse a cidade em transportes públicos para cuidar de suas casas e de suas crianças.

De acordo com Lugones (2008), um dos ordenamentos do sistema de gênero moderno/colonial é a organização de um continuum de desumanização das mulheres pelo critério racial, sendo as mulheres brancas desumanizadas em associação com os animais domésticos e pequenos e as mulheres negras e indígenas com animais selvagens e perigosos que devem ser domesticados e explorados. Para hooks (2020), o imperativo da domesticação das mulheres negras se detinha na possibilidade delas se rebelarem e fazerem

\footnotetext{
${ }^{8}$ Informações disponibilizadas no site oficial do Governo Brasileiro: https://www.ipea.gov.br/portal/images/stories/PDFs/TDs/td_2528.pdf
} 
uso do lugar de proximidade da família e das crianças brancas para criar movimentos insurgentes contra a escravidão. A autora indica que o sucesso do escravista estava associado à conduta passiva e obediente das pessoas que ele negociava como objetos e, portanto, era preciso aterrorizar suficientemente as mulheres negras para que elas fossem satisfatoriamente exploradas pelas famílias brancas no serviço doméstico, nas plantações e no cuidado com as/os herdeiras/os da casa grande. Os resquícios e as reminiscências de lógicas de subjugações coloniais, tais como as relatadas, constituem a base formativa de nossos modos de subjetivação e seguem produzindo efeitos na atualidade, em que mulheres negras são compreendidas como mais fortes, mais aptas ao trabalho braçal e mais propensas a aguentar situações adversas. No contexto da pandemia, essa disposição racial de lugares sociais opera como demarcador de quem deve ou não ser colocado em risco, de quem deve ou não ser protegido, de quem pode ou não ficar em casa.

Marta Maria Santana trabalhava na casa do prefeito de Tamandaré desde 2014, e sua filha, Mirtes Renata, passou a trabalhar para a mesma família em 2018. Ambas foram contaminadas pelo novo agente do coronavírus e como Mirtes revelou à imprensa, mesmo assim elas não foram afastadas do trabalho: Marta ficou na casa de praia cuidando dos filhos dos patrões, inclusive do neto Miguel, e Mirtes voltou para Recife acompanhando seus empregadores. No dia 2 de junho, de acordo com a sobrinha de Mirtes, Miguel pediu à mãe para acompanhá-la no trabalho, pois estava com saudades dela por causa do tempo que tinham ficado em cidades distintas (Britto \& Santos, 2020). Nesse mesmo dia, Mirtes desceu do apartamento, localizado no quinto andar de um prédio residencial em bairro nobre de Recife, para atender o pedido da patroa de passear com o animal de estimação dela. Para isso, Mirtes solicitou à patroa que olhasse seu filho por aqueles poucos minutos enquanto executava a tarefa demandada. Entretanto, quando voltou ao prédio, Mirtes escutou o porteiro dizendo que alguém tinha caído e, ao se direcionar ao local da queda, identificou seu filho Miguel, ainda vivo. Em desespero, gritando por socorro e pedindo ajuda, Mirtes em nenhum momento soltou a coleira do cachorro, posse de sua patroa sob sua responsabilidade.

Miguel caiu de um andar ao qual ele só teria acesso pelo elevador de serviço, outra velha tradição do racismo estrutural, toque de segregacionismo que compõem devidamente os enquadramentos dessa tragédia/crime que remota uma ordem colonial ainda vigente. Miguel foi acompanhado até o elevador pela patroa de Mirtes e foi deixado ali à própria sorte; ao sair do elevador, ele encontrou a queda de aproximadamente 35 metros, por um acesso que só existia pelo elevador de serviço. A queda foi fatal para $o$ menino que apenas tinha iniciado a vida. Enquanto acontecia essa tragédia/crime que dilacerou uma mãe e ceifou a vida de uma criança negra em tão tenra idade, a patroa seguia fazendo suas unhas com uma manicure domiciliar, outro serviço executado majoritariamente por mulheres negras e também considerado essencial durante a pandemia pelo governo federal. Miguel será reconhecido como mais uma vítima da pandemia da Covid-19? Será reconhecido como mais uma vítima do racismo que mata crianças e jovens negros todos os dias nesse país? Logo, o que se apresenta como essencial é alimentar a branquitude em sua demanda imprescindível de ser servida e cuidada em suas necessidades básicas? Ou prevenir que pessoas como Cleonice, Marta, Mirtes e Miguel sucumbam ao novo agente do coronavírus e às iniquidades sociorraciais?

Corroborando com o que nos indica Collins (2016), Mirtes reconhece que qualquer gentileza que possa ter experienciado nos anos de serviço doméstico nada mais foram do que um mecanismo de mantê-la suficientemente disposta a colaborar com as necessidades de seus empregadores. Após tomar conhecimento das imagens dos vídeos de segurança do prédio, que mostram a patroa deixando seu filho sozinho no elevador, Mirtes pede justiça e reconhece que se fosse o contrário ela estaria presa enquanto a pessoa que estava responsável por seu filho teve uma série de benefícios garantidos e, em rede nacional, afirmou que sentia ter feito tudo que estava a seu alcance (Isto é, 2020). A construção dos modos de subjetivação da branquitude está calcada em sua onipotência, ao passo que no caso da mulher branca ela se funda também no recurso sempre disponível de sua fragilidade (Carneiro, 2005; Lugones, 2008, Collins, 2016). Vestida de branco, com um crucifixo no pescoço e falando em tom brando, a patroa encarnou a representação da pureza e da inocência que o sistema de gênero moderno/colonial forjou à sua imagem e semelhança. Ali, sem máscaras, a branquitude afirma que confia na justiça, pois essa tem sua cor e 
sua cara. Para a mãe de Miguel, a ausência perpétua de seu filho foi orçada em vinte mil reais, valor da fiança. Essa história é parte de uma repetição histórica que ainda hoje concebe vidas negras como dispensáveis, descartáveis, não humanas. O racismo é pandêmico e não tem critério geracional de risco. Ser mãe de uma criança negra é ter sempre em pauta a sobrevivência de sua prole diante de um Estado que foi estruturado sem admiti-las como humanas.

De acordo com hooks (2020), assim como a violência sexual foi utilizada como mecanismo de tortura das mulheres negras no sistema escravocrata desde a travessia, as crianças negras foram instrumentalizadas como meio de tortura psicológica para suas mães. Para essas mulheres, a maternidade não foi dignificada como algo louvável, mas, sim, percebida como experiência a ser explorada como meio de tortura psicológica e física.

A quantidade de mulheres que morreram durante o parto ou o número de natimortos jamais será conhecido. Mulheres negras com crianças a bordo de navios negreiros eram ridicularizadas, menosprezadas e tratadas com desprezo pela tripulação de escravizadores. Com frequência, os escravizadores violentavam crianças para assistir ao sofrimento da mãe. Em seu relato pessoal sobre a experiência a bordo de um navio negreiro, os Weldon contaram um episódio em que uma criança de 9 meses foi açoitada continuamente por se recusar a comer. Como o espancamento não fez a criança comer, o capitão ordenou que a colocassem em pé dentro de uma panela de água fervendo. Depois de, sem sucesso, tentar outros métodos de tortura, o capitão jogou a criança no chão, provocando sua morte. Não suficientemente satisfeito com esse ato sádico, ele mandou que a mãe jogasse a criança ao mar. A mãe se recusou, mas foi espancada até ceder (hooks, 2020, p. 42-43).

Essa história não ficou restrita aos navios, nem tampouco relata um caso isolado. A construção romântica de maternidade que o cristianismo ocidental produziu para docilizar as mulheres brancas não se estendeu às mulheres não brancas que foram desumanizadas ao redor do mundo pela incisiva colonial. Associadas a figuras míticas, demoníacas, hiperssexualizadas e bestiais, mulheres indígenas, negras, árabes e asiáticas foram reduzidas a corpos exploráveis, violáveis, animalescos (Shohat, 2002; Carneiro, 2005; Lugones, 2008; Chicangana-Bayona \& González Sawczuk, 2009), corpos que representam, no imaginário moderno/colonial, a antítese da figura branca, virginal e marianista de mãe.

Queiroga (1988) constata em suas análises que no Brasil escravocrata era recorrente que os escravizadores anunciassem o aluguel de mulheres negras logo após o parto para amamentação, dispondo do corpo delas como objeto de sua propriedade e destituindo-as da convivência com seus filhos em prol dos lucros que esse tipo de transação possibilitava. Desse modo, a maternidade, instituição compulsoriamente definida como parâmetro identitário para as mulheres, foi e segue sendo uma das experiências que o racismo nega direta e indiretamente às mulheres negras e indígenas nesse país.

No Brasil contemporâneo, tortura-se mulheres em serviços nos quais deveriam ser ofertados saúde, cuidado e acolhimento. São modos institucionalizados de tortura a negação da analgesia, de acompanhante na hora do parto, toques excessivos, humilhações pautadas em pressuposições sobre a vida sexual, mutilações desnecessárias; sendo essas violências relativizadas em máximas racistas que reiteram a desumanização de mulheres não brancas por meio da afirmação que essas suportam mais dor, que são mais fortes e que carregam crianças ilegítimas - crianças como as que outrora foram sacrificadas em alto mar, depois nas plantações e hoje são sacrificadas indiretamente com o sucateamento das políticas de saúde, de educação, de assistência e de moradia e diretamente em decorrência da ação do Estado, como ocorre em operações policiais em favelas.

\section{Edméia, Bruna: Mães em luto, em luta, em busca de justiça}

Para as mulheres negras, parir e maternar um menino negro no Brasil é conviver constantemente com o medo, com a insegurança, com a apreensão do que é um desfecho recorrente para esses jovens e de algum modo também para elas. Onze jovens, dentre os quais sete adolescentes, foram levados do sítio onde estavam em Magé por um grupo de homens armados que se identificaram como policiais. Era 26 de julho de 1990 e eles não foram encontrados desde então. Esse episódio, conhecido como a Chacina de Acari, dá início a um novo capítulo na vida das mulheres que eram mães desses onze jovens, ali cada uma delas 
adquire uma nova identidade, Mãe de Acari, mães em luta e em luto. Em contextos nos quais o terrorismo é estatal, Mãe é uma identidade política. Edméia da Silva Euzébio, mãe do adolescente Luiz Henrique da Silva Euzébio, uma das vítimas da chacina de Acari, desde o desaparecimento de seu filho, assumiu o propósito de lhe fazer justiça. Juntamente com Vera Lúcia Flores Leite, mãe de Cristiane Souza Leite, e Marilene Lima de Souza, mãe de Rosana Souza Santos, criaram o movimento Mães de Acari que denunciou a nível local, nacional e internacional a Chacina de Acari como uma violação de Direitos Humanos enquanto reivindicavam respostas acerca de onde estavam suas/seus filhas/os.

A mãe que busca justiça por sua/seu filha/o ou o corpo da/o sua/seu filha/o cuja morte é presumida é uma imagem familiar a nós, latino-americanas/os, porque as desigualdades estruturais e a naturalização da violência impôs para muitas mulheres o luto precoce por suas/seus filhas/os. Edméia da Silva Euzébio, ao investigar de modo independente o desaparecimento de seu filho, mesmo sob ameaça de morte e da negação do Estado em protegê-la, tornou-se também - como muitas outras mães - vítima do Estado que promoveu, ocultou ou anistiou o assassinato de seu filho. Dois anos após a Chacina de Acari, em 1993, Edméia da Silva Euzébio foi assassinada em via pública. Sete sujeitos foram indiciados como réus, entre esses seis policiais militares, o processo por sua vez, ainda não foi julgado (Agência Brasil, 2020). A pergunta que fez Edméia se tornar uma vítima também segue sem resposta: o que aconteceu com os onze jovens que desapareceram no episódio conhecido como a Chacina de Acari?

Os vinte e um anos de regime militar, nos quais torturas, execuções, sequestros, estupros e uma série infindável de violências tornaram-se institucionalmente parte da rotina dos agentes do Estado, não foi um episódio isolado na história do Brasil. Ao contrário disso, representou um episódio coerente com a história de autoritarismo e de violência desse país. As práticas dos oficiais durante os anos da ditadura são reproduções de práticas perpetradas por escravizadores, colonizadores, capatazes e todos aqueles que acreditavam na autoridade de subjugar o outro pela eliminação de seu senso de humanidade. Esse modo de funcionamento subjetivo-político não se encerra com a redemocratização. Como indica Adorno (1995), o que se observa nos anos subsequentes é a sistemática violação de Direitos Humanos por parte de policiais, principalmente por meio do abuso de populações desprovidas de proteção legal, tais como os grupos discriminados racialmente, crianças e adolescentes, trabalhadoras/os rurais e defensoras/res de direitos humanos implicadas/os na causa ambiental, muitas/os delas/es negras/os e indígenas.

A Chacina de Acari no início da década de 1990 antecede episódios igualmente trágicos e que fizeram com que essa ficasse conhecida como a Era das Chacinas. A chacina da candelária, a chacina de Vigário Geral e a chacina do Carandiru são eventos que denotam o habitus naturalizado de extermínio da população negra por agentes do Estado. Esse modo de funcionamento se mantém nos anos 2000 e tem em um de seus episódios mais graves o que ficou conhecido como os Crimes de Maio:

Entre os dias 12 e 20 de maio de 2006, no estado de São Paulo, policiais e grupos paramilitares de extermínio promoveram um dos mais vergonhosos escândalos da história brasileira. Em uma cínica e mentirosa "onda de resposta" ao que se chamou na grande imprensa de "ataques do PCC", foram assassinadas no mínimo 493 pessoas que hoje constam entre mortas e desaparecidas. Há estudos, no entanto, que apontam para um número ainda maior de assassinatos no período, considerando ocultações de cadáveres, falsificações de laudos e outros recursos utilizados por tais agentes públicos violentos. Um acontecimento terrível, em suma, que vitimou sobretudo jovens pobres - negros e afro-indígena-descendentes executados sumariamente por policiais e grupos de extermínio ligados ao estado. Dos quais, é importante se ressaltar, não há sequer um caso de policiais que tenham sido devidamente investigados, julgados e punidos conforme a própria lei orienta (Mães de Maio, 2011, p. 18).

O sistema de gênero moderno/colonial que organizou hierarquicamente o valor da vida a partir da naturalização de ficções como raça e gênero (Lugones, 2008) segue com sucesso promovendo o extermínio físico, psíquico, epistemológico, simbólico e político de pessoas negras (Carneiro, 2005). No intuito de visualizar os contornos atuais do projeto eugenista de branqueamento pela eliminação do povo negro, defendemos que é essencial compreender que esse é 
estruturalmente generificado. Observemos a massificação da esterilização de mulheres negras como meio de evitar que esse grupo populacional fosse maioria no Brasil (Damasco, Maio, \& Monteiro, 2012), estratégia interseccionalmente racista, classista e generificada, tal como o genocídio de jovens negros.

O extermínio de jovens negros por forças militares e paramilitares é um crime substancialmente racializado e generificado que se mantém como prática efetiva do projeto eugenista da sociedade brasileira ao longo do tempo e que não se encerrou na Era das Chacinas, nem com o absurdo dos Crimes de Maio, haja vista os dados apresentados no Atlas da Violência (Instituto de Pesquisa Econômica Aplicada \& Fórum Brasileiro de Segurança Pública, 2019, p. 49):

Em 2017, 75,5\% das vítimas de homicídios foram indivíduos negros (definidos aqui como a soma de indivíduos pretos ou pardos, segundo a classificação do IBGE, utilizada também pelo SIM), sendo que a taxa de homicídios por $100 \mathrm{mil}$ negros foi de 43,1 , ao passo que a taxa de não negros (brancos, amarelos e indígenas) foi de 16,0 . Ou seja, proporcionalmente às respectivas populações, para cada indivíduo não negro que sofreu homicídio em 2017, aproximadamente, 2,7 negros foram mortos.

As vítimas de homicídio têm nome, mas raramente esses são ditos em voz alta. O assassinato de jovens negros já era uma pandemia silenciada que vitima milhares de pessoas todos os anos. Perdemos, desse modo, uma grande parte da geração de homens negros devido ao risco de serem homens e negros num país que construiu uma perversa cadeia associativa sobre eles. De acordo com Kilomba (2019, p. 130): "O racismo não é biológico, mas discursivo. Ele funciona por meio de um regime discursivo, uma cadeia de palavras e imagens que por associação se tornam equivalente". No Brasil a associação da negritude à criminalidade tem produzido estratégias efetivas de extermínio do povo negro, a maioria delas pelas mãos dos agentes do Estado em nome da falaciosa "guerra contra as drogas". Nesse sentido, a cadeia de associação Preto-Pobre-FaveladoTraficante-Criminoso-Violento-Temível-PerigosoInimigo tem tido como principal efeito o genocídio da juventude negra brasileira a partir da ação de policiais que entendem qualquer corpo negro masculino como um alguém a ser combatido.

Marcus Vinicius tinha 14 anos de idade e estava indo para escola quando foi alvejado na comunidade da Maré, em junho de 2018. Sua mãe, Bruna Silva, trabalhadora doméstica, diz que em seus últimos momentos o filho lhe dizia que foi o blindado que havia atirado nele e questionava: "eles não viram que eu tava com roupa da escola?" (Betim, 2018). Bruna Silva, após ter que enterrar seu filho, iniciou sua luta por justiça e levava na mão a farda escolar manchada com o sangue do garoto. Não demorou muito tempo para que uma nova luta se impusesse a ela, a saber: o combate à vinculação de notícias falaciosas que acusavam Marcus Vinicius de ser traficante. Mesmo tendo perdido a vida, é o adolescente que precisa de defesa e não seus assassinos. Logo, a saga de Bruna Silva é pela justiça e também pelo direito de resguardar a memória do filho que encontrou a morte no caminho da escola. Se boa parte do Brasil descobriu o medo de sair de casa e encontrar a morte pelo contágio do novo agente do coronavírus, a juventude negra no Brasil conhece esse temor de outros tempos. Ser negro e periférico parece ser suficiente para ser considerado um envolvido no tráfico de drogas e logo um alvo justificável da ação policial, independentemente da idade.

Como resgata Vieira (2012), o Tráfico de Drogas é tipificado pela Organização Internacional do Trabalho (OIT) e pela regulamentação do decreto $\mathrm{n}^{\circ}$ 6.481, de junho de 2008, como uma das piores formas de trabalho infantil, assim como a escravidão, a exploração sexual e o recrutamento para lutas armadas. No entanto, apenas o tráfico é motivo para que o adolescente seja considerado alvo de penalização e não de proteção do Estado. No Brasil, a suposta guerra às drogas é fator recorrente nas justificativas acerca das mortes perpetradas por agentes do Estado em exercício da função. $\mathrm{O}$ alegado envolvimento com o tráfico de drogas das vítimas é instrumentalizado como atenuante para o fato de que eles foram vitimados sem julgamento. Ou seja, a presunção do envolvimento de um jovem negro em muitos casos implica em pena capital instantânea em qualquer esquina desse país.

$\mathrm{Na}$ pandemia, mesmo com as orientações de reclusão domiciliar e de isolamento social, os jovens negros não estão mais seguros. Como divulgado pela Rede de Observatórios da Segurança (2020), entre 15 de março e 19 de maio de 2020 foram 
monitoradas 209 operações no estado do Rio de Janeiro, com 69 mortes. Só no mês de abril houve $58 \%$ mais mortes nessas operações do que no mesmo período no ano anterior (Ramos, Paiva, \& Nunes, 2020). Quem está sendo protegida/o se o adolescente João Pedro Matos Pinto, de apenas 14 anos de idade, foi assassinado numa dessas operações, enquanto brincava com seus primos dentro da casa de seu tio? Quem se sente protegida/o quando sabe que suas/seus filhas/os podem ser levadas/os sem seu consentimento e aparecer sem vida dias depois? A crise sanitária escancara o absurdo do racismo institucional brasileiro. Por mais que haja comoção em torno do caso de João Pedro, não há surpresa tampouco tempo para o luto. Apenas dois dias depois da morte de João Pedro, João Victor Gomes da Rocha, de apenas 18 anos de idade, foi alvejado numa operação policial na Cidade de Deus. O conselheiro tutelar que acompanhou o pai no reconhecimento do corpo disse que o jovem tinha saído pra comprar uma pipa. No momento do tiroteio, o grupo Frente Cidade de Deus estava fazendo uma campanha de distribuição de 200 cestas básicas para famílias da comunidade que vivem a pandemia agravada pela falta de comida, água limpa e saneamento (Aidar, 2020), revelou pelo Twitter que sofreu intimidação e ameaças pelos policiais que faziam a operação, mesmo tendo justificado a razão de sua presença no local.

No dia seguinte à morte de João Victor, o vendedor ambulante e estudante Rodrigo da Conceição foi morto em uma ação policial em frente ao Colégio Estadual Reverendo Hugh Clarence Tucker no Morro da Providência, onde estava prevista a distribuição de 50 cestas básicas arrecadadas pela própria comunidade escolar (Almeida, 2020). Rodrigo, que fazia parte dessa comunidade escolar, foi descrito pelos professores como um jovem de óculos grossos que sentava próximo ao quadro para poder copiar a matéria. Contudo, esse mesmo jovem foi indicado pelos policiais como um suspeito, sendo baleado e, em seguida, levado na viatura a contragosto das/os moradoras/ es que acreditavam que Rodrigo ainda estaria vivo. De acordo com Adorno (1995), a população não confia nas instâncias de justiça no Brasil, levando à existência de um grande vazio institucional produzido pela falta de credibilidade de que os agentes públicos estejam de fato a serviço e proteção da sociedade.

Ao se organizar para distribuir cestas básicas, denunciar os excessos da polícia militar e contar quem realmente eram os jovens reduzidos ao estigma da criminalidade, comunidades de pessoas negras reivindicam o direito ao luto e a funerais ainda não realizados. Impedidos pelo racismo antes mesmo que a pandemia extinguisse nossa prática de ritualizar a morte. Os jovens de Acari nunca foram encontrados, muitas das vítimas dos Crimes de Maio ainda estão desaparecidas. No Brasil, o extermínio não ocorre apenas quando localizamos um corpo, pois saber que foi levado pela polícia já inspira projeções pessimistas e a desolação do impedimento de poder velar seus mortos, lembrar de suas histórias e escrever seus nomes em mármore, madeira ou concreto. Isto é, escrever seus nomes sobre a insígnia da saudade e não do extermínio.

\section{Sobre uma viagem em águas revoltas}

A imagem de George Floyd, um homem negro de 46 anos de idade, sendo sufocado por um policial branco em Minneapolis, no dia 25 de maio de 2020, disparou pelo mundo afora como uma fagulha para milhões de pessoas negras sufocadas diariamente pelo racismo que foi imposto aos povos não brancos pelo marco civilizatório colonial. Em meio à pandemia de uma doença que compromete o sistema respiratório e que tem como principal artifício de controle respiradores mecânicos, a voz de George Floyd dizendo que não conseguia respirar nos faz lembrar de muitas outras vozes que tiveram o ar roubado.

Uma mulher negra de 51 anos de idade, sem o nome revelado por medo de retaliações, dias após o assassinato de George Floyd, foi agredida por um policial em São Paulo, que repetindo a imagem de violência que aconteceu nos Estados Unidos, ajoelhou-se em seu pescoço, impedindo-a de respirar. Diferentemente de 381 pessoas mortas, entre janeiro a abril desse ano no estado de São Paulo em decorrência de intervenções de agentes da segurança pública (Arcoverde, 2020), a referida vítima sobreviveu a esse ato genocida. Contudo, os discursos oficiais seguem a tratar casos como esse como exceção na prática policial. Claudia Ferreira da Silva, mulher negra de 38 anos de idade, foi baleada por policiais em uma operação no Morro da Cegonha e, em seguida, arrastada pela viatura da Polícia Militar do Rio de Janeiro, no dia 16 de março de 2014. Toda essa cena foi filmada e amplamente divulgada, mas os autores de tal crime nunca foram penalizados. 
A violência brutal destinada às pessoas negras é uma violência gratuita que acontece "não por causa do que fazem, mas por causa de quem são, ou melhor, de quem não são" (Vargas, 2017, p. 96), instaurando, desse modo, um estado contínuo de terror racial. São tantas histórias não contadas de sufocamento de vidas negras que acontecem nesse país desde a travessia forçada de africanas/os pelo Atlântico no período da colonização, submetendo, a partir de então, o povo negro a condições de vida em que o ar se torna permanentemente rarefeito, levando à morte simbólica, social e física.

Portanto, falta-nos ar quando uma mulher negra é estuprada e/o morta por seu companheiro. Falta-nos ar quando um adolescente negro é baleado rumo a escola. Falta-nos ar quando um homem negro é assassinado na frente de sua família a caminho de um chá de bebê. Falta-nos ar quando o Sistema Único de Saúde (SUS) é precarizado. Falta-nos ar quando não se tem água potável e segurança alimentar na casa de inúmeras famílias negras. Falta-nos ar quando uma mulher negra tem sua vida colocada em risco por não ter direito ao aborto legal e seguro. Falta-nos ar quando é negado o direito à moradia. Falta-nos ar quando uma jovem travesti negra é encontrada morta embaixo de um viaduto. Logo, nos faltará ar enquanto o racismo for a base de sustentação de todas as formas de opressão desse país.

Há séculos o racismo se estrutura em nossa sociedade provocando violações de direitos, violências e mortes diárias a pessoas negras, não se reduzindo, portanto, a atos isolados que ganham breves holofotes das grandes mídias e, em alguns casos, parca e temporária comoção social. É importante questionar o que a atual pandemia revela e a quem, tendo em vista as significativas manifestações públicas de espanto frente ao racismo e suas consequências, impulsionadas pela circulação das imagens do assassinato de George Floyd.

Em um país autoritário e violento como o Brasil, atos racistas ainda são comumente vistos com olhares de desconfiança, de surpresa e/ou interpretados como um deslize individual. Isso obstaculiza o enfrentamento ao racismo estrutural por novamente esvaziar a historicidade da opressão racial de modo a fragmentar o sofrimento negro e a individualizar questões que são coletivas. Consequentemente, reforça a naturalização da violência impelida ao corpo negro, além de relativizar o sofrimento negro e o afastar da lembrança (Flauzina, 2017), produzindo apagamentos que nos impede de simbolizar e politizar a nossa história. Por isso, escrevemos aqui um memorial de palavras, no qual nomes que insistem em ocultar da história oficial, sejam registrados como vítimas da colonialidade e do racismo estrutural, ambos potencializados no contexto de crise sanitária que vivemos.

Mesmo sufocadas pelo sistema de gênero moderno/colonial, as mulheres negras têm projetado suas vozes nos espaços públicos, movimentado estruturas sociais ao contar suas histórias e partilhar seus saberes, além de resistido com seus corpos as incursões genocidas do Estado. A crise sanitária em curso tem visibilizado a complexidade das experiências das mulheres negras a partir de suas posicionalidades nas estruturas de poder, haja vista que elas compõem um dos grupos sociais mais impactados pela pandemia da Covid-19, ao mesmo tempo em que assumem posições de protagonistas em ações de prevenção e cuidado de suas famílias e comunidades.

Contudo, não se trata de romantizar histórias que são talhadas com letras de dor e de sangue e/ ou reproduzir cegueira geradas pelas lentes do racismo patriarcal que tratam as experiências das mulheres negras como sobrenaturais e as desenham como guerreiras que tudo aguentam e suportam (Akotirene, 2018). É a urgência pela sobrevivência que mobiliza a força das mulheres negras, advinda de experiências concretas de um passado marcado pela escravização (Davis, 2016) que se reencena no presente. É premente a construção de formas coletivas de redistribuição do peso da responsabilidade depositada sobre os ombros das mulheres negras pelo cuidado e preservação das comunidades negras em diáspora. Isso implica na necessidade de criar e/ ou potencializar outras configurações de subjetividades, sociabilidades e poder que criem frestas nas estruturas racistas e patriarcais, além de tensionar o Estado que desde o Brasil colônia segue a ofertar políticas de migalhas, jogando à deriva alguns botes salva-vidas e regurgitando discurso salvacionista, frente ao naufrágio que ele mesmo arquitetou.

Há muitos desafios a serem enfrentados, haja vista que ainda estamos profundamente mergulhadas/os em uma pandemia que já demonstrou a emergência de um fenômeno que não é apenas biológico, mas também social e político, cujos efeitos 
provavelmente irão perdurar por um tempo indeterminado. Alguns dizem que estamos vivenciando o novo normal, outros anseiam que voltemos à normalidade perdida. É sabido que em ambos os contextos não há lugar seguro para as vidas negras. Por isso, é urgente gerar novas fagulhas e mobilizar a raiva e o ódio que a falta de ar nos provoca para projetar com radicalidade o antigo e atual sonho de liberdade negra. Para Audre Lorde (1981), a raiva é potencialmente útil para gerar mudanças pessoal e institucional, em suas palavras a "raiva é cheia de informação e energia". Almejamos que a raiva fomente a nossa imaginação e ação política, nos levando, inclusive, ao rompimento de aderências irrefletidas a epistemologias patriarcais, brancas e ocidentais pautada numa racionalidade genocida que nega nossa existência.

\section{Referências}

Akotirene, C. (2015). O que é interseccionalidade. Belo Horizonte: Letramento.

Arcoverde, L. (2020, 1 de Junho). Mortes cometidas pela polícia entre janeiro e abril de 2020 crescem $31 \%$ em São Paulo. G1. https://g1.globo.com/sp/sao-paulo/noticia/2020/06/01/mortes-cometidas-pela-policia-entrejaneiro-e-abril-de-2020-crescem-31 percent-em-sp.ghtml

Adorno, S. (1995). Violência, Estado e sociedade: Notas sobre desafios à cidadania e à consolidação democrática no brasil. Cadernos CERU, 6(sup), 37-51.

Agência Brasil. (2020, 26 de Julho). Mães de Acari inspiram luta por direitos humanos 30 anos após chacina. Correio Braziliense. https://www.correiobraziliense.com.br/app/noticia/brasil/2020/07/26/interna-brasil,875567/maesde-acari-inspiram-luta-por-direitos-humanos-30-anos-apos-chacina.shtml

Aidar, B. (2020, 20 de Maio). Grupo que distribuía cestas básicas em comunidade fica preso em tiroteio. Metrópoles. https://www.metropoles.com/brasil/policia-br/grupo-que-distribuia-cestas-basicas-em-comunidade-ficapreso-em-tiroteio

Almeida, P. (2020, 12 de Maio). Tiros interrompem distribuição de cestas básicas; homem é morto pela PM. Notícias UOL. https://noticias.uol.com.br/cotidiano/ultimas-noticias/2020/05/21/tiros-interrompem-distribuicao-decestas-basicas-pelo-segundo-dia-seguido.htm

Betim, F. (2018, 25 de Junho). Mãe de jovem morto no Rio: "É um Estado doente que mata criança com roupa de escola”. El País. https://brasil.elpais.com/brasil/2018/06/22/politica/1529618951_552574.html

Brasil. (2017, 1 de Fevereiro). Portaria n ${ }^{\circ}$ 344, de 12 de Maio de 1998. Ministério da Saúde.

Britto, D., \& Santos, M. C. (2020, 5 de Junho). Mãe e avó de Miguel contraíram Covid-19 e nem assim foram dispensadas do trabalho. Ponte Jornalismo. https://ponte.org/mae-e-avo-de-miguel-contrairam-covid-19-e-nem-assimforam-dispensadas-do-trabalho/

Carneiro, A. S. (2005). A construção do outro como não-ser como fundamento do ser (Publicação no 001465832), (Tese de doutorado). Universidade de São Paulo, São Paulo, SP, Brasil.

Chicangana-Bayona, Y. A., \& González Sawczuk, S. I. (2009). Bruxas e índias filhas de Saturno: Arte, bruxaria e canibalismo. Estudos Feministas, 17(2), 507-526. https://doi.org/10.1590/S0104-026X2009000200012

Collins, P. H. (2016). Aprendendo com a outsider within: A significação sociológica do pensamento feminista negro. Sociedade e Estado, 31(1), 99-127. https://dx.doi.org/10.1590/S0102-69922016000100006

Covid-19 e os Povos Indígenas (2020). Plataforma de monitoramento da situação indígena na pandemia do novo coronavírus (Covid-19) no Brasil. https://covid19.socioambiental.org/

Davis, A. (2016). Mulheres, raça e classe (1a ed., H. R. Candiani, Trad.). Boitempo.

Damasco, M. S., Maio, M. C., \& Monteiro, S. (2012). Feminismo negro: Raça, identidade e saúde reprodutiva no Brasil (1975-1993). Estudos Feministas, 20(1), 133-151. https://doi.org/10.1590/S0104-026X2012000100008

Flauzina, A. L. P. (2017). Pelo amor ou pela dor: Apontamentos sobre o uso da violência como resistência ao genocídio. In A. L. P. Flauzina \& J. C. H. Vargas (Orgs.), Motim: horizontes do genocídio antinegro na Diáspora (pp. 151-169). Brado Negro.

${ }^{9}$ Disponível em: https://arquivoradical.wordpress.com/2017/01/21/os-usos-da-raiva-mulheres-respondendo-ao-racismo/. 
Fellet, J. (2020, 2 de Março). Após saída de médicos cubanos, mortes de bebês indígenas crescem 12\% em 2019. BBC News Brasil. https://www.bbc.com/portuguese/brasil-51593460.

Goes, E. F., Ramos, D. O., \& Ferreira, A. J. F. (2020). Desigualdades raciais em saúde e a pandemia da Covid-19. Trabalho, Educação e Saúde, 18(3), 1-7. https:// doi.org/10.1590/1981-7746-sol00278

Gonzales, L. (1984). Racismo e sexismo na cultura brasileira. Revista Ciências Sociais Hoje, 223-244.

Grosfoguel, R. (2018). Para uma visão decolonial da crise civilizatória e dos paradigmas da esquerda ocidentalizada. In J. Bernardino-Costa, N. Maldonado-Torres, \& R. Grosfoguel (Orgs.), Decolonialidade e pensamento afrodiaspórico (pp. 55-77). Autêntica Editora.

hooks, b. (2020). Eu não sou uma mulher? Mulheres negras e feminismo (3a ed.). Rosa dos Tempos.

Instituto Brasileiro de Geografia e Estatística. (2010). Censo Demográfico 2010: Características gerais dos indígenas: Resultados do universo. IBGE. https://biblioteca.ibge.gov.br/visualizacao/periodicos/95/cd_2010_ indigenas_universo.pdf

Instituto Brasileiro de Geografia e Estatística. (2015). Pesquisa nacional de saúde 2013: Acesso e utilização dos serviços de saúde, acidentes e violências: Brasil, grandes regiões e unidades da federação. IBGE. https:// biblioteca.ibge.gov.br/visualizacao/livros/liv94074.pdf

Instituto de Pesquisa Econômica Aplicada \& Fórum Brasileiro de Segurança Pública (Orgs.). (2019). Atlas da violência. IPEA. https://www.ipea.gov.br/portal/images/stories/PDFs/relatorio_institucional/190605_atlas_da_ violencia_2019.pdf

Instituto Socioambiental \& Coordenação Nacional de Articulação das Comunidades Negras Rurais Quilombolas. (2020). Observatório da Covid-19 nos Quilombos. Quilombo Sem Covid-19. https://quilombosemcovid19.org/

Isto é. (2020, 5 de Julho). "Sinto que fiz tudo que podia", diz Sari Corte Real em entrevista ao Fantástico. https://istoe.com.br/sinto-que-fiz-tudo-que-podia-diz-sari-corte-real-em-entrevista-ao-fantastico/

Jesus, V. (2020). Racializando o olhar (sociológico) sobre a saúde ambiental em saneamento da população negra: Um continuum colonial chamado racismo ambiental. Saúde e Sociedade, 29(2), 1-15. https://dx.doi.org/10.1590/ s0104-12902020180519

Kilomba, G. (2019). Memórias da plantação: Episódios de racismo cotidiano (1a ed., J. Oliveira, Trad.). Cobogó.

Lima, B., \& Cardim, M. E. (2020, 2 de Junho). Conselho Federal de Psicologia tem aumento de pedidos de consultas virtuais. Correio Braziliense. https://www.correiobraziliense.com.br/app/noticia/brasil/2020/06/02/ interna-brasil,860185/conselho-federal-de-psicologia-tem-aumento-de-pedidos-de-consultas-vir.shtml

Lorde, A (2017, 21 de Janeiro). Os usos da raiva: Mulheres respondendo ao racismo. Arquivo Radical. https://arquivoradical.wordpress.com/2017/01/21/os-usos-da-raiva-mulheres-respondendo-ao-racismo/

Lugones, M. (2008). Colonialidad y género. Tabula Rasa, (9), 73-102.

Mães de Maio. (2011). Do luto à luta. São Paulo: Artes Gráficas Giramundo.

Mayorga, C. (2013). Sobre mulheres, psicologia, profissão e a insistente ausência das questões raciais. In Conselho Federal de Psicologia, Psicologia: Uma profissão de muitas e diferentes mulheres (pp. 173-200).

Mbembe, A. (2016). Necropolítica. Arte e ensaios, (32), 123-151. https://revistas.ufrj.br/index.php/ae/article/view/8993

Mbembe, A. (2017). Políticas da inimizade (la ed., M. Lança, Trad.). Lisboa: Antígona.

Moreira, R. B., \& Pereti, E. (2020). A árvore do esquecimento e as tentativas de destruição da memória afrodiaspórica. Revista Uniabeu, 13(33), 284-297. https://revista.uniabeu.edu.br/index.php/RU/article/view/3860

Nascimento, A. (2017). O Genocídio do negro brasileiro: Processo de um racismo mascarado. São Paulo: Perspectiva. (Trabalho original publicado em 1978)

Neide, R. (2020). Projeto de Lei $n^{\circ}$ 1142, de 2020. https:/ / www.camara.leg.br/propostas-legislativas/2242218

Organização das Nações Unidas. (2020, 2 de Junho). ONU alerta para impacto desproporcional da Covid-19 sobre minorias raciais e étnicas. UNIC Rio de Janeiro. https://unicrio.org.br/ onu-alerta-para-impacto-desproporcional-da-covid-19-sobre-minorias-raciais-e-etnicas/

Queiroga, M. M. (1988). A família negra e a questão da reprodução. Anais do VI Encontro de Estudos Populacionais, 3, 323-340. 
Quijano, A. (2005). A colonialidade do poder, eurocentrismo e América Latina. In Lander, E. (Org.), A colonialidade do saber: Eurocentrismo e ciências sociais: Perspectivas latino-americanas (pp. 227-278). Clacso.

Ramos, S., Paiva, A., \& Nunes, P. (2020, 26 de Maio). Máquina de matar. Rede de Observatórios da Segurança. http://observatorioseguranca.com.br/2020/05/

Rede de Observatórios da Segurança. (2020). Racismo, motor da violência: Um ano da Rede de Observatórios da Segurança. CESeC. http://observatorioseguranca.com.br/wp-content/uploads/2020/07/Racismo-motor-daviolencia-1.pdf

Ribeiro, D. (2020, 19 de Março). Doméstica idosa que morreu no Rio cuidava da patroa contagiada pelo coronavírus. Folha de São Paulo. https://wwwl.folha.uol.com.br/colunas/djamila-ribeiro/2020/03/domesticaidosa-que-morreu-no-rio-cuidava-da-patroa-contagiada-pelo-coronavirus.shtml

Rodríguez, D. (2017). O genocídio racial/racial-colonial e a lógica de evisceração: Radicalismo negro como resposta prática e guia teórico. In A. L. P. Flauzina, \& J. H. C. Vargas. (Orgs.), Motim: Horizontes do genocídio antinegro na diáspora (pp. 11-35). Brado Negro.

Shohat, E. (2002). A vinda para a América: Reflexões sobre perda de cabelos e de memória. Estudos Feministas, 10(1), 99-117. https:// doi.org/10.1590/S0104-026X2002000100006

Vargas, J. (2017). Por uma mudança de paradigma: Antinegritude e antagonismo estrutural. In A. L. P. Flauzina, \& J. H. C. Vargas (Orgs.), Motim: Horizontes do genocídio antinegro na Diáspora (pp. 91-105). Brado Negro.

Vieira, A. K. (2012). "Dá nada pra nós" (?): O real do encarceramento de adolescentes (Dissertação de Mestrado). Universidade Federal de Minas Gerais, Repositório UFMG, Belo Horizonte, MG, Brasil.

\section{Paula Rita Bacellar Gonzaga}

Professora Assistente na Universidade Federal do Sul da Bahia, Doutoranda em Psicologia Social na Universidade Federal de Minas Gerais, vinculada ao Núcleo de Pesquisa Conexões de Saberes, Itabuna - BA. Brasil

E-mail: paularitagonzaga@gmail.com

(1) https://orcid.org/0000-0001-7095-5345

\section{Vivane Martins Cunha}

Doutoranda em Psicologia na Universidade Federal de Minas Gerais. Vinculada ao Núcleo de Ensino, Pesquisa e Extensão Conexões de Saberes, Belo Horizonte - MG. Brasil.

E-mail: cunha.vivane@gmail.com

(1) https://orcid.org/0000-0002-5125-2529

Endereço para envio de correspondência:

Faculdade de Filosofia e Ciências Humanas da Universidade Federal de Minas Gerais. Av. Presidente Antônio Carlos, 6627, sala 2005, Pampulha. CEP: 31270-901. Belo Horizonte - MG. Brasil.

Recebido 28/08/2020

Aceito 28/08/2020

Received $08 / 28 / 2020$

Approved 08/28/2020

Recibido 28/08/2020

Aceptado 28/08/2020 
Como citar: Gonzaga, P. R. B., \& Cunha, V. M. (2020). Uma pandemia viral em contexto de racismo estrutural: Desvelando a generificação do genocídio negro. Psicologia: Ciência e Profissão, 40, 1-17.

https://doi.org/10.1590/1982-3703003242819

How to cite: Gonzaga, P. R. B., \& Cunha, V. M. (2020). A viral pandemic in the context of structural racism: Unveiling black genocide. Psicologia: Ciência e Profissão, 40, 1-17. https://doi.org/10.1590/1982-3703003242819

Cómo citar: Gonzaga, P. R. B., \& Cunha, V. M. (2020). Una pandemia viral en el contexto del racismo estructural: Develando la generificación del genocidio de la población negra. Psicologia: Ciência e Profissão, 40, 1-17. https://doi.org/10.1590/1982-3703003242819 